\title{
Die kerk universitas of societas? juridies besien
}

\author{
JC Oelofse
}

1

Prof Botha het in sy versoek aan my om hierdie vraag te behandel, gestel dat "na die mislukte kerkvereniging van 1885 het daaruit 'n hofsaak gespruit in verband met eiendomme van die Nederduitsch Hervormde Kerk. Die uitspraak van die hof in 1893 was dat die kerk 'n universitas was en nie 'n societas nie" en dat $u$ "uit 'n juridiese oogpunt die saak nader toegelig wil hê en ook die vraag beantwoord wou sien of dit steeds so gesien word".

\section{2}

In $\mathrm{u}$ vraag stel $\mathrm{u}$ 'n societas teenoor ' $n$ universitas. Dit is noodsaaklik om ter aanvang die twee begrippe behoorlik onder oë te sien en te bepaal wat daaronder verstaan moet word.

3

Voordat die twee begrippe onder oë gesien word moet die begrip "regspersoon" eers van naderby bekyk word. ' $n$ "Regspersoon" is in teenstelling met ' $n$ natuurlike persoon kunsmatig en denkbeeldig. Dit is ' $n$ entiteit met ' $n$ naam van sy eie sonder ' $n$ fisiese bestaan, wat alleen maar bestaan in die beskouing van die reg en waaraan die reg persoonlikheid verleen, dit wil sê die bevoegdheid van regte te verkry en verpligtinge aan te gaan.

4

In streng juridiese sin word 'n "societas" normaalweg as 'n vennootskap gesien.

In $u$ vraag waar $u$ 'n societas teenoor ' $n$ universitas stel moet daar klaarblyklik ' $n$ breër betekenis aan die begrip geheg word. In die breë sin van die woord sluit societas, afgesien van vennootskap, ook 'n geselskap, 'n vereniging en ' $n$ broederskap in.

Kragtens die gemenereg is ' $n$ vennootskap nie 'n regspersoon nie en word deur die vorming van 'n vennootskap nie ' $n$ entiteit, afsonderlik van die individuele vennote, geskep nie. Daar kan dus tot die 
gevolgtrekking gekom word dat wanneer 'n societas teenoor 'n universitas gestel word, soos in u vraag, met societas enige liggaam bedoel word wat nie met regspersoonlikheid beklee is nie.

\section{5}

'n Universitas daarteenoor is ' $n$ regsfiksie, 'n samevoeging van individue wat ' $n$ persona of entiteit vorm wat oor die bevoegdheid beskik om regte te verkry en verpligtinge aan te gaan tot' $n$ hoë mate net soos 'n natuurlike persoon en met ewigdurende opvolging. ' $n$ Universitas word van 'n blote vereniging van individue (sonder regspersoonlikheid) onderskei deur die feit dat dit 'n entiteit is wat duidelik onderskeibaar is van die individue wat dit vorm, dat die bevoegdheid om regte te verkry en verpligtinge aan te gaan duidelik onderskeibaar is van die ooreenstemmende bevoegdhede van die lede en wat verkry of aangegaan word vir die liggaam as geheel, en nie vir die individuele lede daarvan nie. 'n Universitas sou ons dus kon definieer as ' $n$ liggaam wat met regspersoonlikheid beklee is.

6

Omdat ' $n$ universitas ' $n$ regspersoon is, kan dit eiendom verkry, hou en vervreem. Dit kan ooreenkomste sluit en so 'n krediteur of ' $n$ skuldenaar word. Dit kan ander persone onreg aandoen en skaad en kan self ook veronreg en skade berokken word. Dit kan aksies instel en kan gedagvaar word.

\section{7}

Dit volg uit die voorgaande dat die belangrikste eienksappe van 'n universitas die volgende is:

71

dat dit afsonderlik van die individue wat dit saamstel, bestaan

72

dat daar ewigdurende opvolging aanwesig is

73

dat dit eiendom kan besit afsonderlik van die lede. 
In die Suid-Afrikaanse reg word daar duidelik onderskei tussen verenigings wat met regspersoonlikheid beklee is en verenigings wat nie met regspersoonlikheid beklee is nie. Verenigings wat wel met regspersoonlikheid beklee is word in twee kategorieë verdeel naamlik statutêre verenigings soos byvoorbeeld bouverenigings en koöperatiewe verenigings, en gemeenregtelike verenigings. Omdat die Nederduitsch Hervormde Kerk nie 'n statutêre vereniging is nie word die ondersoek beperk tot gemeenregtelike verenigings d.w.s. daardie verenigings wat met regspersoonlikheid beklee word kragtens die gemenereg.

9

Vanweë bepalings wat vervat is in die Maatskappyewet $\mathrm{nr} 61$ van 1973, kan alle verenigings ook nie kragtens die gemenereg met regspersoonlikheid beklee word nie. Die wet bepaal o.a.:

\section{1}

dat geen vereniging wat sake wil doen met wins as oogmerk en wat uit meer as twintig lede bestaan in die RSA toegelaat word nie

\section{2}

dat geen vereniging van persone wat na 31 Desember 1939, opgerig is en wat sake doen met wins as oogmerk, 'n regspersoon is nie, tensy sulke verenigings as maatskappye geregistreer word òf ingevolge 'n ander wet opgerig word òf voor 31 Mei 1962 opgerig is ingevolge 'n Patentbrief of Koninklike Oktrooi.

10

Die doel wat 'n vereniging nastreef, moet natuurlik wettig wees.

11

Hierdie vereistes waaraan verenigings moet voldoen ten einde gemeenregtelik met regspersoonlikheid beklee te word en dus 'n universitas personarum te kan wees, is deur die Suid-Afrikaanse howe in talle sake neergelê. Die vereistes soos vroeër gestel, staan dus in die Suid-Afrikaanse reg vas. 
Of ' $n$ vereniging van persone aan hierdie vereistes voldoen, is ' $n$ feitelike vraag wat in die algemeen afhang van die geaardheid van die vereniging, sy konstitusie, sy doelstellings en sy aktiwiteite. As die Nederduitsch Hervormde Kerk nou aan hierdie vereistes getoets word, is dit duidelik:

\section{1}

dat die kerk as ' $n$ vereniging van persone beskou moet word;

\section{2}

dat die kerk afsonderlik van die lidmate wat dit saamstel, bestaan. Dit is duidelik a aparte entiteit;

\section{3}

dat daar in die kerk ewigdurende opvolging aanwesig is. Die bepalings van die Kerkwet (konstitusie) is in die verband baie duidelik en ek is dus nie van voorneme om $u$ met ' $n$ uiteensetting daarvan te vermoei nie;

\section{4}

dat die kerk eiendom kan besit afsonderlik van die lidmate. Ook in hierdie verband is die bepalings van die Kerkwet glashelder;

\section{5}

dat die kerk 'n wettige doel nastreef;

126

dat die kerk as sodanig nie sake doen met 'n winsoogmerk nie.

13

Die Kerk voldoen dus ongetwyfeld aan die vereistes wat in die SuidAfrikaanse reg gestel word vir 'n vereniging van persone om 'n universitas personarum te wees. Hierdie siening word bevestig deur die beslissing in die Standertonsaak van 1893. In die beslissing word 
sonder meer uitgegaan van die standpunt dat die Kerk 'n universitas is. In talle sake waarin die Kerk daarna betrokke was, is eweneens aanvaar dat die Kerk 'n universitas is.

14

Daar kan dus onomwonde gestel word dat die Nederduitsch Hervormde Kerk ' $n$ universitas personarum is.

15

Daar dien ook nog opgemerk te word dat die Transvaalse Provinsiale Afdeling van die Hooggeregshof in die Kempsaak beslis het dat die kerk 'n uniale kerk is en nie federaal nie.

16

Ten slotte dien ook opgemerk te word dat die belang van die Standertonsaak nie daarin geleë is dat die hof aanvaar het dat die kerk'n universitas is nie, maar daarin dat die hof uitgemaak het dat

"De ontbinding van een zedelijk lichaam of van eene universitas, door besluit harer leden, kan alleen geschieden door toestemming van al de leden, zoo- de Algemene Vergadering eener Kerk niet bij meerderheid van stemmen er toe mag overgaan het Kerkgenootschap te doen eindigen in haar zelfstandig bestaan door haar met een ander te vereenigen; noch de eigendommen er van overmaken mag aan anderen, zonder de toestemming van alle leden."

Dit is tans nog die posisie in die Suid-Afrikaanse reg.

\section{Bronnelys}

The Elements of Jurisprudence - TE Holland

Roman Private Law - Max Kaser

Cassell's Latin Dictionary

The South African Judicial Dictionary - JJL Sisson

Law of Contract in SA - Wessels

Voet: Commentary on the Pandects

Principles of SA Law - Wille

SA Mercantile and Company Law - Gibson

Partnerships and Voluntary Associations - Bamford

The Law of SA (Vol 1)

De Nederduitsch Hervormde Gemeente van Standerton vs De Nederduitsche Hervormde of Gereformeerde Gemeente van Standerton $1893 \mathrm{H} 84$ 
W] Kemp vs Die Nederduitsch Hervormde Kerk van Afrika TPA ongerapporteer (1956) Webb \& Co Ltd vs Northern Rifles, Hobson \& Sons vs Northern Rifles 1908 TS 462

Ex parte Johannesburg Congregation of the Apostolic Church 1968 (3) SA 377 Ex parte Gill and Others 1955 (2) SA 418

Malebjoe vs Bantu Methodist Church of SA 1957 (4) SA 465

Moloi vs St John Apostolic Faith Mission 1954 (3) SA 940

Klerksdorp and Dist. Muslim Merchants Associa vs Mahomed 1948 (4) SA 731

Maatskappyewet Nr 61 van 1973 